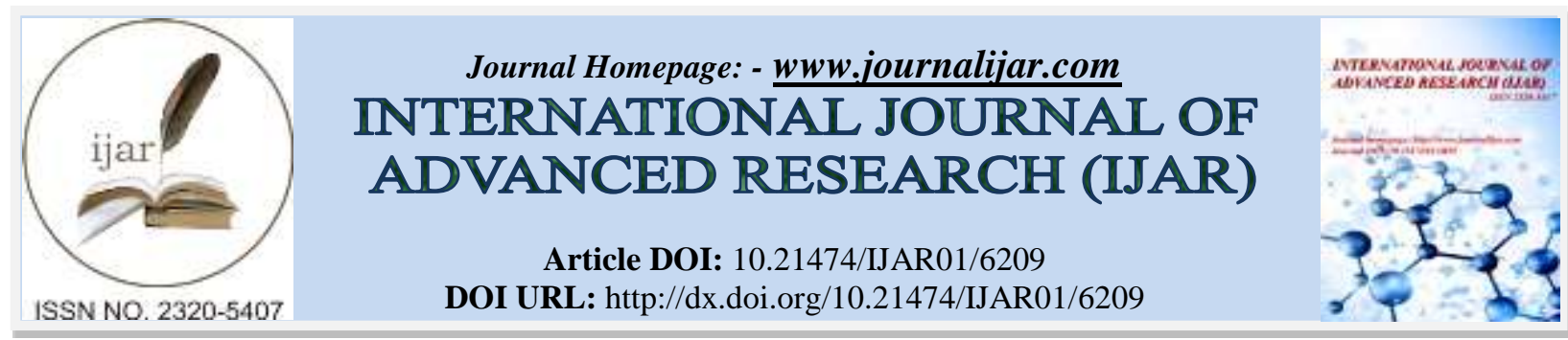

RESEARCH ARTICLE

\title{
THE EFFECT OF ENTREPRENEURSHIP ORIENTATION, INFORMATION TECHNOLOGY, STRATEGIC PLANNING TO COMPETITIVE ADVANTAGES WITH BUSINESS PERFORMANCE AS INTERVENING VARIABLES: EMPIRICAL STUDY FOOD PROCESSING SMEs IN NORTH SULAWESI.
}

Billy Josef Anis, Budiman Christiananta and Lena Ellitan. School of Post Graduate, Widya Mandala Catholic University Surabay, Indonesia.

\section{Manuscript Info}

Manuscript History

Received: 04 November 2017

Final Accepted: 06 December 2017

Published: January 2018

\begin{abstract}
This study aims to examine the influence of Entrepreneurship Orientation, Information Technology, Strategic Planning, to Business Performance and Competitive Advantage of micro and small entrepreneurs of food processing industry in North Sulawesi. In the case of the existence of micro and small entrepreneurs in this area, especially the processed food processing industry being studied, micro and small entrepreneurs are expected to build their ability to compete more and give quality value to the product. The logic of the model to be built in this study refers to how the Orientation of Entrepreneurship is formed in micro and small entrepreneurs of the food processing industry. Addition of information technology variables, as well as strategic planning is to see the development of business performance and competitive advantage of the respondents studied. The population of this research is food processing industry in North Sulawesi. Respondents are the owners who directly manage the company with a sample size of 132 respondents. Data collection was done by survey respondents, with data analysis using AMOS. The results showed that the Orientation of Entrepreneurship (X1), Information Technology (X2), Strategic Planning (X3) influenced the positive direction on Business Performance (Y1) and Competitive Excellence (Y2) of micro and small food industry. The use of Information Technology in micro and small entrepreneurs has become a reference factor in marketing their products to the online market. Several managerial suggestions were also submitted on the findings of the research findings.
\end{abstract}

Copy Right, IJAR, 2018,. All rights reserved.

\section{Introduction:-}

The development of a country's economic model aims to stimulate all sectors of the economy to move forward and develop into forces on a regional and national scale. Micro, small and medium enterprises (SMEs) have become one of the most effective machines in developing economic market patterns in almost all countries and regions. Data from the Ministry of Cooperatives and SMEs, in 2013 SMEs is able to donate 5,440 Trillion rupiahs (at current prices) to the National Gross Domestic Product (GDP) which absorbs 114,14 million workers and attracts 1,655.2 trillion rupiahs in total investment business as much as 57.8 million units (Sari et al. 2015: 16). 
Meanwhile, various internal and external factors also influence the competitiveness of SMEs. The still low level of innovation in Indonesia adds to the weight of competition to the open market. Added by Sari et al. (2015: 53) in Bank Indonesia's working paper that the factors of low innovation and inhibiting SMEs to go forward include the following low technological mastery, especially for micro and small enterprises, awareness to expand the reach of marketing through e-commerce, low ownership of international or national certification (SNI), and ease of doing business.

Along with the Economic Policy Package X Year 2015, the Central Government has issued a package of investment easing while enhancing the protection for Micro, Small, Medium Enterprises and Cooperatives (SMEs) in the business sector reserved for SMEs. The government seeks to create a significant investment climate including food and beverage processing industries that contribute positively to the provision of jobs. The food and beverage processing industry is part of the revenue contributors of the State and receives a large portion of attention in its development plan by the Government.

North Sulawesi Province with good economic growth, must be ready with all competition of the ASEAN conomic Community (MEA). Of course, the competition to support the data of MSMEs North Sulawesi Province 2015 as many as 69,853 consisting of micro business 48,772 units, small businesses 19,139 units and medium businesses 1,942 units that can absorb labor up to 171,436 people. For the sake of supporting economic growth and the provision of business field, the processing industry including food is best prepared to face the era of ASEAN Economic Community (MEA). Processing industries, especially food and beverage processing industries for North Sulawesi Province should be more established in production in the future. Quality, package, and processing should be more secure before being given to the buyer's market.

As part of the contribution of economic growth, the processing industry is expected to continue to grow in the next year to further drive the industry, especially the household sector and small industries. In terms of demand and supply, the development of processing industry in North Sulawesi Province is still very possible to develop more leverage especially food processing industry.

Table 1:- Addition of Small and Medium Industry Data According to Industry Branch in North Sulawesi Province 2014-2015.

\begin{tabular}{|l|c|c|c|c|}
\hline Business Categories & \multicolumn{2}{|c|}{2014} & \multicolumn{2}{c|}{2015} \\
& SMEs & Employee & SMEs & 736 \\
\hline Food & 194 & 601 & 166 & 1671 \\
\hline & 32 & 77 & 151 & 654 \\
\hline Clothing & 87 & 267 & 241 & 317 \\
\hline Chemichal Industry & 77 & 184 & 77 & 221 \\
\hline Total & 53 & 108 & 371 & 3030 \\
\hline
\end{tabular}

Source: North Sulawesi Province in Figures 2015 and 2016 (242,217)

The addition of data of small and medium industries in 2014 and 2015 in North Sulawesi Province looks quite encouraging as an indicator of business development and employment as part of reducing unemployment. Data Table 2 signifies the positive movement of industry additions the last two years which is certainly very useful to support local investment.

Table 2:- Addition of Small and Medium Industry Data According to Branch of Food Industry in North Sulawesi 2014-2015

\begin{tabular}{|l|r|r|r|r|}
\hline City & \multicolumn{2}{|c|}{$\begin{array}{c}\text { Year 2014 } \\
\text { Business Unit of Labor }\end{array}$} & \multicolumn{1}{c|}{ Business Unit of Labor } \\
\hline & & & & 45 \\
\hline Bolmong & 19 & 51 & 6 & 21 \\
\hline Minahasa & 9 & 26 & 1 & 3 \\
\hline Kepulauan Sangihe & 13 & 37 & - & - \\
\hline Kepulauan Talaud & 11 & 81 & 20 & 34 \\
\hline Minahasa Selatan & 11 & 33 & & \\
\hline
\end{tabular}




\begin{tabular}{|l|r|r|r|r|}
\hline MInahasa Utara & 35 & 100 & 291 & 779 \\
Bolmut & 3 & 4 & - & - \\
SiTaRo & - & - & 78 & 168 \\
Minahasa Tenggara & 52 & 135 & 30 & 67 \\
Bolmong Selatan & 10 & 34 & 16 & 40 \\
Bolmong Timur & 21 & 63 & 55 & 67 \\
\hline & & & 5 & 11 \\
\hline Manado & 1 & 4 & 1 & 4 \\
\hline Bitung & - & - & 209 & 418 \\
\hline Tomohon & - & - & 6 & 19 \\
\hline Kotamobagu & 9 & 33 & 736 & 1671 \\
\hline Total & 194 & 601 & & \\
\hline
\end{tabular}

Source: North Sulawesi Province in Figures 2015 and 2016 (241,215).

As an area of its mention Nyiur Melambai, North Sulawesi Province has become a granary production for the food industry. The food processing industry as shown in Table 2 has illustrated the good development of the increasing number of industries in the last 2014-2015. If seen in almost every city in North Sulawesi Province is so easy to find business people, especially household (micro) in every corner of the place of business. It tends to be said that there are still many data of micro industry actors (household) of food processing industry that have not been included in Government data. The cause of their data has not been accommodated, among others, most of them are engaged in an already open industry with online and do not need a place where the cost of rent becomes a burden for these micro actors. Micro industry actors are spreading rapidly and their activities are more mobile with consumers and markets they already know through online orders.

The proliferation of businesses in the Food Processing Industry in North Sulawesi, which continues to move significantly now, is increasingly open to the direction of this research. The openness of the role of the Governor of North Sulawesi Province currently has a positive impact on economic development in this province including Food Processing Industry. As a province in the northernmost part of the State, it turns out that micro and small industry actors, including food processing industries, have grown and many of them already have household food product registers (PIRT). These early signs are positively encouraging for the development of the food processing industry. With the PIRT register will pave the way to product quality and safety. It is a big surprise for the development of micro and small actors in the food processing industry that has been innovating through the use of PIRT ownership awareness in North Sulawesi Province.

Is the presence of food processing industry actors in North Sulawesi currently using online media, having PIRT registers starting from the household or micro and small industries that have evolved almost in all the districts of North Sulawesi province also positively deliver performance and competitive advantage for them, this is certainly the subject of research whether the businessman is starting with a high entrepreneurial orientation or just follow the flow without a clear plan.

Current problems in the food processing industry in North Sulawesi Province have not been fully synchronized with the readiness of professional processing, quality and market standard. The orientation of entrepreneurship and planning strategy of SMEs and government synergy is not yet fully established. The data that has been identical to the progress of this food processing industry is still not seen as a potential region in North Sulawesi. Making the product of the famous processed food industry like in the islands of Java, seems still a very important homework to do. This business actor has not been indicated as a business that can make a trade mark income for those who exist in this industry. In terms of demand and supply and the opening of foreign tourist market exceeds the average of the visit as the impact of the current governor's policy direction, the development of processing industry in North Sulawesi Province is still highly possible to develop more leverage especially the food processing industry.

The joint role of the Government is certainly in line with the programs that have been implemented through the Department of Industry and Trade of North Sulawesi Province. Related agencies, in 2017 has started the development of SMEs small business e-smart (SMEs) through the use of digital e-commerce-based economy. Direct online usage supports the concept of Digital Economy Ecosystem promoted by the Government through State Owned Enterprises (SOEs) selected since 2016. According to the Government, the adoption of digital technology 
from SMEs should be done using the principle of USE (Usefulness, Suitableness, Ease of Use). It is a pity if North Sulawesi does not contribute mainly to the processed food industry. Because the phenomenon of food and beverage processing industry development in Indonesia according to Central Government data is very potential in the Year 2017. The focus of this study aims to examine the influence of the use of Orientation of Entrepreneurship, Information Technology, Strategic Planning in Presenting Business Performance and Excellence Competing micro and small entepreneurs food processing industry or also often called food processing industry in North Sulawesi Province.

\section{Literature review:-}

Darsono (2013) quotes Winardi (2004) that Joseph Schumpeter's view of the function of the entrepreneur is to change and revolutionize production patterns by exploiting a new invention. According to Asmarani (2006: 6) quoted from Hartanto (1999) argued, the turmoil facing the business world today is not only due to changes in the external environment, but also the consequences of the development and internal changes of each company. Competitive Excellence Measures refer also to what Grant (2002) has to say. The company is said to have a Competitive Advantage when it reaches a higher profit level than its competitors. Resource-Based Theory through most users of research says Resource-Based View (RBV) is as one of the most accepted theories for Competitive Advantage. The rapid development of Information Technology (IT) today, not only related to the era of the emergence of computers and devices to support all business activities. Information Technology has changed as other inventors create applications that are very useful to the entire business world and used by entrepreneurs around the world. For inventors, self-created apps are initially to benefit from their patents and support potential future businesses. The existence of economic reciprocity, the owners of Information Technology world such as Microsoft, Facebook, Google as an example see the applications is an advantage that regardless of the value they must buy in order to maintain their performance and excellence in the global competition of Information Technology market. The adoption of Information Technology in Indonesia is still relatively low. Research findings such as in Mardijono (2009) and Setyawati et al. (2014) is also a reference of this study. Surely some researchers are quite doubtful about the potential of Information Technology being the source of Competitive Advantage by arguing, the exploration of Information Technology and its implementation is not really connected to superior performance (Barney and Clark, 2007: 144). Use of Information Technology both IT applications realize the importance of the meaning of the theory of Red Queen Effect for entrepreneurs. This means that if you want to reach another place in quick time, it must run at least twice as fast (Caroll, 1872). The results of research conducted Pure (2014) in his research explain the negative relationship is not significant Orientation of Entrepreneurship to the performance of SMEs batik. Research $\mathrm{Li}$ et al. (2006) resulted that the Orientation of Entrepreneurship has a positive effect on company performance. Positive positive relationship of entrepreneurship orientation to organizational performance is also obtained through research of Covin and Slevin (1991). Mahmood and Hanafi (2013) in his research resulted in a significant influence between the Orientation of Entrepreneurship and Competitive Advantage. Rauch et al. (2004) finds some indication that sizes moderate the relationship of Orientation of Entrepreneurship and Performance, where the relationship is stronger in micro-enterprises than in small businesses. Differences in research results encourage researchers to study the influence of the Orientation of Entrepreneurship on performance.

Through the research of Nasir and Oktari (2012) shows that the utilization of Information Technology has no effect on the performance of Government Institutions. While Keramati (2007) through the research "A survey in Iran Car Part Suppliers Sector" mentions that there is a significant positive result between the use of technology to the performance of the company. Meanwhile, Mardijono (2009) concluded that the utilization of Information Technology has a positive effect on the organization's performance in Temanggung District Hospital. As per Wilson et al. (2015) entitled "Effects of Information Technology on Performance Logistics Firms in Nairobi County" mentions the high level of use of Information Technology in the company means more effective and efficient company. . The study by Sager (1988) stated totally negative results to the relationship of Information Technology and Competitive Advantage. . Through Setyawati et al. (2014) with the results of the study resulted that the adoption of Information Technology influence on the performance of entrepreneurship and the adoption of Information Technology influence on Excellence Competing SMEs food beverage industry in Bandung. Aslizadeh (2014) in his research entitled Impact of Using Information Technology On Creating A Sustainable Competitive Advantage For Companies (Case Study: Golestan Food Companies) states the results of his research that a positive relationship means between "the use of information technology" and "the creation of a competitive advantage" in food company in Golestan. Research Langat and Auka (2015) suggests Strategic Planning on small businesses where. Their results explain the relationship between strategy formulation and company performance. Through the study Dinda Estika Asmarani (2006) explains the relationship Strategic Planning has a significant positive effect on company 
performance. The results of subsequent research Asmarani also states accept that the company's performance has a positive and significant impact on Competitive Advantage. This study is in accordance with the findings of Phillips (2000) which shows a positive result between Strategic Planning with performance that leads to Competitive Advantage.

\section{Hipotesis:-}

In accordance with the development of food processing industry is quite advanced and how the development of industry can be useful positive for micro and small entrepreneurs food processing industry, the research explore the influence of entrepreneurship orientation variables, information technology, strategic planning on business performance and competitive advantage. Hypotheses in this study are as follows:

H1: The Entrepreneurship Orientation has a significant effect on Business Performance of Micro and Small Businesses of Food Processing Industry in North Sulawesi.

H2: The Entrepreneurship Orientation has a significant effect on the Competitive Advantage of Micro and Small Entrepreneurs of Food Processing Industry in North Sulawesi.

H3: Information Technology has a significant effect on Business Performance of Micro and Small Businesses of Food Processing Industry in North Sulawesi.

H4: Information Technology has a significant effect on the Competitive Advantage of Micro and Small Businesses of Food Processing Industry in North Sulawesi.

H5: Strategic Planning has a significant effect on Business Performance of Micro and Small Businesses of Food Processing Industry in North Sulawesi.

H6: Strategic Planning has a significant effect on the Competitive Advantage of Micro and Small Entrepreneurs of Food Processing Industry in North Sulawesi.

H7: Business performance has a significant effect on the Competitive Advantage of Micro and Small Businesses of Food Processing Industry in North Sulawesi.

\section{Research Methods:-}

The population in this research is all micro and small entrepreneurs of food processing industry of North Sulawesi Province especially food processing industry in North Minahasa Regency, Sangihe Regency, Talaud Islands Regency, Manado City and South Minahasa Regency. The basis of population determination in this study is data Year 2015 amounting 67,911 business units consisting of micro business 48,772 units, small businesses 19,139 units. Research criteria based on Law no. 20 Year 2008 on the provisions of the scale of micro and small enterprises. Analyzer in this research is using Structural Equation Modeling (SEM), Hair et al. (2010: 444). The number of samples used is 132 people (respondents) where the data represent the Regency and City of North Sulawesi Province studied. Sampling technique is Proportional Random Sampling Area is a sampling technique that can be used in stratified population, population area or cluster population where the respondents are micro and small entrepreneurs who can be met directly in the field at the time of the research conducted. Exogenous variables in this study are Entrepreneurship Orientation Variable (X1), Variable Information Technology (X2), Strategic Planning Variables (X3). Intervening variable in this research is Business Performance Variable (Y1). And Endogen Variable in this research is Competitive Advantage Variable (Y2)

\section{Results and Discussion:-}

Research data obtained respondents who work in this food processing industry. Sex data questionnairesquestionnaires obtained by men of 47 people or $36 \%$ and women amounted to 85 people or $64 \%$. This means the results of the questionnaire indicate that women in the study are more involved in this industry activity. , the number of worker employed is $\leq 2$ people equal to 97 respondents $(73 \%), \leq 3$ persons 30 respondents $(23 \%)$, and $\leq 5$ persons 5 respondents (4\%). The number of workers in the respondents examined certainly has another meaning that the food processing industry this area has not required the use of relatively many workers. But if the food processing industry is increasingly perceived benefits for prospective entrepreneurs, then the addition of business means will increase the provision of employment and useful for equitable income. The income side of the business per month of the respondents is described by 58 respondents earning <Rp. 5 million and 74 respondents earned Rp. 5 million Rp. 10 million. This data indicates that the respondents who studied the absence of respondents of micro and small entrepreneurs of this food processing industry whose income per month is more than Rp. 10 million. 
Table 3:- Results of Model Path Coefficient Testing Competitive Advantage

\begin{tabular}{|c|c|c|c|c|}
\hline Variable & Coeficient & C.R. & Prob. & Significance \\
\hline $\begin{array}{l}\text { Orientation of entrepreneurship (X1) } \\
\square \text { Competitive performance (Y1) }\end{array}$ & .391 & 3.615 & .000 & Significance \\
\hline $\begin{array}{l}\text { Information technology (X2) } \\
\square \text { Competitive performance (Y1) }\end{array}$ & .204 & 2.327 & .020 & Significance \\
\hline $\begin{array}{l}\text { Strategic planning (X3) } \square \text { Competitive } \\
\text { performance (Y1) }\end{array}$ & .196 & 2.023 & .043 & Significance \\
\hline $\begin{array}{l}\text { Orientation of entrepreneurship (X1) } \\
\square \text { Competitive advantage (Y2) }\end{array}$ & .170 & 2.656 & .008 & Significance \\
\hline $\begin{array}{l}\text { Information technology (X2) } \square \\
\text { Competitive advantage (Y2) }\end{array}$ & .135 & 2.658 & .008 & Significance \\
\hline $\begin{array}{l}\text { Strategic planning (X3) } \square \text { Competitive } \\
\text { advantage (Y2) }\end{array}$ & .899 & 8.662 & .000 & Significance \\
\hline $\begin{array}{l}\text { Business performance (Y1) } \square \text { Competitive } \\
\text { advantage (Y2) }\end{array}$ & .290 & 4.632 & .000 & Significance \\
\hline
\end{tabular}

Based on Table 3, the interpretation of each path coefficient is as follows:

1. The entrepreneurship orientation (X1) has a significant effect on the positive direction on business performance (Y1). It can be seen from the coefficient of positive sign of 0.391 with the value of C.R. amounted to 3.615 and obtained a probability significance (p) of 0.000 which is smaller than the significance level specified at 0.05 . Thus the entrepreneurship orientation (X1) directly affects the business performance (Y1) of 0.391, which means that any increase in entrepreneurship orientation (X1) will improve business performance (Y1).

2. Information technology (X2) has a significant effect on the positive direction of business performance (Y1). This can be seen from the coefficient of the path marked positive by 0.204 with the value of C.R. 2,327 and the probability significance (p) of 0,020 is smaller than the specified significance level of 0.05 . Thus Information technology (X2) has an effect on business performance (Y1), which means that any improvement of information technology (X2) will affect business performance improvement (Y1).

3. Strategic planning (X3) has a significant effect on the positive direction of business performance (Y1). This can be seen from the coefficient of positive sign of 0196 with the value of C.R. of 2.023 and obtained a probability significance $(\mathrm{p})$ of 0.043 which is smaller than the significance level specified at 0.05 . Thus strategic planning (X3) has a direct effect on business performance (Y1) of 0.196 , which means that any increase in strategic planning (X3) will improve business performance (Y1).

4. The entrepreneurship orientation (X1) has a significant effect on the positive direction of competitive advantage (Y2). This can be seen from the coefficient of positive sign of 0.170 with the value of C.R. of 2,656 and the probability significance (p) of 0.008 is lower than the significance level $(\square)$ determined at 0.05 . Thus the entrepreneurship orientation (X1) directly affects the competitive advantage (Y2) of 0.170, which means any increase in entrepreneurship Orientation (X1) will increase competitive advantage (Y2).

5. Information technology (X2) has a significant effect on the positive direction of competitive advantage (Y2). This can be seen from the coefficient of positive sign of 0.135 with the value of C.R. equal to 2,658 and obtained significance probability $(\mathrm{p})$ equal to 0,008 smaller than level of significance which is determined equal to 0,05. Thus Information technology (X2) has an effect on Competitive Advantage (Y2), which means that every increase of Information Technology (X2) will affect the improvement of competitive advantage (Y2).

6. Strategic planning (X3) has a significant effect on the positive direction of competitive advantage (Y2). This can be seen from the coefficient of positive sign of 0999 with the value of C.R. of 8,662 and obtained a probability significance $(\mathrm{p})$ of 0.000 which is smaller than the specified significance level of 0.05 . Thus Strategic Planning (X3) directly affects Competitive Advantage (Y2) of 0.899, which means that any increase in Strategic Planning (X3) will increase competitive advantage (Y2).

7. Business performance (Y1) has a significant effect on the positive direction of competitive advantage (Y2). This can be seen from the coefficient of positive sign of 0.290 with the value of C.R. of 4,632 and obtained a probability significance (p) of 0.000 which is smaller than the specified significance level ( $\square$ ) of 0.05 . Thus the business performance (Y1) directly affect the competitive advantage (Y2) of 0.290, which means that any improvement in business performance (Y1) will increase competitive advantage (Y2). 


\section{Conclusions and Recommendations:-}

Based on the results of data testing, then obtained results that illustrate the significant influence with the positive direction of each variable tested. Although the answer to this study has been answered, it becomes an important homework because the results data resulted in the absence of respondents with significant income on the viability of the food processing industry. Online use through the utilization of information technology is very helpful and has become the needs of entrepreneurs who researched. The entrepreneurial orientation of micro and small entrepreneurs is significant data on their impact on their performance and competitive advantage.

For that as a suggestion in the future, hopefully active cooperation will be established between the Government and the micro and small entrepreneurs of this food processing industry. The existence of entrepreneurs helps to reduce the unemployment and employment. Certainly the positive development of micro and small entrepreneurs will reduce the burden of the Government in relation to the unemployment rate. The government will also have a positive impact on the economic distribution of the impact of the existence of micro and small entrepreneurs in the food processing industry.

\section{References:-}

1. Aslizadeh, A (2014). Impact of Using Information Technology on Creating a Sustainable Competitive Advantage for Companies; (Case study: Golestan Food Companies). Indian Journal of Fundamental and Applied Life Sciences, 4(54), $1595-1603$.

2. Asmarani, Dinda Estika (2006). Analisis Pengaruh Perencanaan Strategi Terhadap Kinerja Perusahaan Dalam Upaya Menciptakan Keunggulan Bersaing. Tesis, Universitas Diponegoro Semarang.

3. Barney, Jay. B and Delwyn, N. Clark (2007). Resource-Based Theory: Creating and Sustaining Competitive Advantage. Oxford University Press.

4. Carroll, L. (1872). Through the Looking-Glass, and What Alice Found There. Macmillan \& Co., London.

5. Covin, J.G and Slevin (1991). A Conceptual Model of Entrepreneuship as Firm Behaviour, Entrepreneuship Theory and Practice (Fall), $7-25$.

6. Darsono, Nurdasila (2013). Orientasi Kewirausahaan dan Keunggulan Bersaing serta Kinerja Usaha Mikro, Universitas Syiah Kuala Darussalam Banda Aceh.

7. Grant, R. M (2002). Contemporary Strategic Analysis, $4^{\text {th }}$ Ed. Oxford: Blackwell.

8. Langat, Jackline Chepngeno and Auka, Daniel Onwonga (2015). Effects of Strategic Planning on performance of medium sized enterprises in Nakuru town. Journal of Business Administration and Management Sciences Research, $4(2), 49-59$.

9. Li, Yong-Hui, Huang, Jing-Wen and Tsai, Ming-Tien (2006). Entrepreneurial orientation and Firm Performance: The Role of Knowledge creation process, Industrial Marketing Management.

10. Mahmood, Rosli and Hanafi, Norshafizah (2013). Learning Orientation and Business Performance of Women-Owned SMEs in Malaysia: The Mediating Effect of Competitive Advantage. British Journal of Arts and Social Sciences, $11(2), 150-161$.

11. Mardjiono, Didik Eko (2009). Analisis Pengaruh Kepemimpinan, Pemanfaatan Teknologi Informasi dan Implementasi Struktur Organisasi yang terdesentralisasi terhadap Kinerja Organisasi. Studi Pada RSUD Kabupaten Temanggung, Tesis Universitas Padjajaran.

12. Murni, Tri (2014). Pengaruh Orientasi Kewirausahaan Terhadap Kemampuan Manajemen, Strategi Low Cost, Strategi Diferensiasi, Inovasi Berkelanjutan dan Kinerja Usaha Kecil dan Menengah (UKM), Disertasi, Fakultas Ilmu Administrasi Universitas Brawijaya Malang.

13. Nasir, Azwir dan Oktari, Ranti (2012). Pengaruh pemanfaatan Teknologi Informasi dan Pengendalian Intern Terhadap Kinerja Instansi Pemerintah.

14. Phillips, P.A (2000). The Strategic Planning/Finance Interface: Does Sophistication Really Matter? Management Decision, 38(8), $541-549$.

15. Sari, Yunita Resmi., Manullang, Noviarsono., Anas Titik., Narjoko, A. Dionisius., Simangunsong, Andre., Purwanti, Wini., Khulasoh, Lisa and Paramitha, Fadila. (2015). Pemetaan dan Strategi Peningkatan Daya Saing UMKM dalam Menghadapai MEA 2015 dan Pasca MEA 2025. Working Paper, Bank Indonesia.

16. Sager, Michael T (1988). "Competitive Information Systems in Australian Retail Banking." Information \& Management 15, 1 (August 1988): 59 - 68.

17. Setyawati, Amelia., Nimran, Umar., Zulkhirom, Moch., and Kumadji, Sri Kandi. (2014). Effect of Strategic Decision, Innovation, and Information Technology Adoption on Competitive Advantages and MSME Performance. Studies at MSME Food and Beverage Industry Sector in Bandung Raya. European Journal of Business and Management, vol. 6 no. 35,52 .

18. Wilson, Macharia Ngombo., Iravo, Mike. A., Tirimba, Ondabu Ibrahim and Ombui, Kepha (2015). Effects of information Technology on Performance of Logistics Firms in Nairobi County. International Journal of Scientic and Research Publication, 5(4), $1-26$. 